\title{
Evidence for Related Virulence Sequences in Plasmids of Salmonella dublin and Salmonella typhimurium
}

\author{
By G. DAVID BAIRD,* E. JANE MANNING AND PHILIP W. JONES \\ AFRC Institute for Research on Animal Diseases, Compton, Newbury RGI6 ONN, UK
}

(Received 6 December 1984; revised 11 March 1985)

\begin{abstract}
Transposon-insertion mutants were prepared from virulent field isolates of Salmonella dublin and Salmonella typhimurium. Detailed restriction-enzyme mapping of the single sites of $\operatorname{Tn} A$ insertion in two mutants (M51 and M173) of S. dublin that showed diminished virulence in a mouse assay indicated that these sites were about $5 \mathrm{kbp}$ apart on the approximately $70 \mathrm{kbp}$ plasmid harboured by the isolate. A Tn10-insertion mutant (M242) of $S$. typhimurium that showed diminished virulence was also identified. A single copy of Tn 10 was inserted into the approximately $90 \mathrm{kbp}$ plasmid harboured by this isolate. Hybridization studies indicated that homology existed between the region encompassing the sites of $\operatorname{Tn} A$ insertion in M51 and M173 and that encompassing the site of Tn 10 insertion in M242. Restriction mapping indicated that the two regions were very similar and could even be identical and, if so, the Tn 10 insertion in M242 could be mapped to a point $1.5 \mathrm{kbp}$ from the $\operatorname{Tn} A$ insertion in M51 and $6.5 \mathrm{kbp}$ from that in M173. It appeared that the maximal extent of the putative similarity/identity was between 13 and $23 \mathrm{kbp}$. It is proposed that this stretch of high homology could represent a virulence sequence that has been conserved during the evolutionary divergence of the two Salmonella serotypes.
\end{abstract}

\section{INTRODUCTION}

Plasmids play a part in the virulence of a number of pathogenic bacteria. For example, plasmids carry genes encoding toxin production, iron sequestration, adhesiveness and serum resistance (Levy et al., 1981).

In the last few years it has been shown by experiments involving curing or conjugational transfer that plasmids play an important role in mediating the virulence of enteroinvasive bacteria such as Shigella and Salmonella. Thus, Sansonetti et al. $(1981,1982)$ showed that the presence of a 185 or a $215 \mathrm{kbp}$ plasmid is necessary to enable Shigella sonnei or Shigella flexneri, respectively, to produce keratoconjunctivitis in the guinea-pig. Similarly, Jones et al. (1982) found that the ability of virulent Salmonella typhimurium strains to adhere to and invade HeLa cells, and to kill mice following oral administration, depends on the presence of a $92 \mathrm{kbp}$ plasmid. Terakado et al. (1983) reported that loss of a $75 \mathrm{kbp}$ plasmid present in numerous virulent Salmonella dublin isolates leads to diminished ability to kill mice following peritoneal inoculation.

Relatively little is known about the nature of the plasmid genes that are involved in virulence expression in these enteroinvasive bacteria, or about the proteins that these genes encode. However, Hale et al. (1983) have been able to associate loss of virulence in Shigella flexneri with a large deletion of unspecified size in the $215 \mathrm{kbp}$ plasmid, and consequent failure to synthesize seven plasmid-encoded outer-membrane polypeptides in minicell experiments.

The present study describes the isolation of two transposon-insertion mutants of Salmonella dublin and one of Salmonella typhimurium that show diminished virulence in a mouse assay.

Abbreviations: Ap, ampicillin; $\mathrm{Cm}$, chloramphenicol; $\mathrm{Km}$, kanamycin; $\mathrm{Tc}$, tetracycline. 
Investigations with these three mutants have led to the identification of regions of the approximately 70 and $90 \mathrm{kbp}$ plasmids present in the $S$. dublin and $S$. typhimurium isolates, respectively, that must play an important role in virulence. There appears to be substantial homology between these regions in the two serotypes, suggesting the presence of conserved virulence sequences. Some preliminary findings have been published (Baird \& Manning, 1984; Manning et al., 1984).

\section{METHODS}

Bacterial strains and plasmid vectors. These are listed in Table 1 . Bacteria were stored in $12 \%(\mathrm{v} / \mathrm{v})$ glycerol at $-70^{\circ} \mathrm{C}$ as described by Silhavy et al. (1984).

Preparation of mutants. Transposon-insertion mutants of S. dublin 2229 and S. typhimurium 1275 were prepared by random insertion of either $\operatorname{Tn} A\left(A p^{r}\right)$, originating on plasmid pMR5 (RP1ts) (Robinson et al., 1980), or of $\operatorname{Tn} 10$ ( $\mathrm{Tc}^{\mathrm{r}}$ ), present in a suicide derivative of phage P22 (Davis et al., 1980).

To prepare Tn $A$-insertion mutants, a copy of plasmid pMR 5 was transferred to the wild-type Salmonella isolate from Escherichia coli K12(pMR5) by conjugation (Miller, 1972). Transconjugants were identified by plating out the conjugation mix on modified brilliant green agar (Oxoid CM329) containing Ap $\left(500 \mu \mathrm{g} \mathrm{ml}^{-1}\right), \mathrm{Km}$ $\left(30 \mu \mathrm{g} \mathrm{ml}^{-1}\right)$ and $\mathrm{Tc}\left(20 \mu \mathrm{g} \mathrm{ml}^{-1}\right)$. Procedures were carried out at $30^{\circ} \mathrm{C}$. Descendants of these transconjugants that were $\mathrm{Apr}$ but $\mathrm{Km}^{\mathrm{s}}$ and $\mathrm{Tc}^{\mathrm{s}}$ after $18 \mathrm{~h}$ growth at $42^{\circ} \mathrm{C}$ on two separate occasions were taken to be $\operatorname{Tn} A$-insertion mutants. Tn 10-insertion mutants were prepared as described for $S$. typhimurium LT2 by Davis et al. (1980). In this method, the suicide phage is prepared by mixing mutant, tail-deficient $\mathrm{P} 22:: \operatorname{Tn} 10$, obtained by inducing the lysogenic strain $S$, typhimurium NK337, with head-deficient P22, obtained by growing P22-503 in a nonsuppressing host (see Table 1). $\mathrm{Tc}^{r}$ descendants of wild-type Salmonella isolates infected with the suicide P22:: $\operatorname{Tn} 10$ were taken to be $\operatorname{Tn} 10$-insertion mutants. The identity and status of all Salmonella mutants were validated using qualitative slide agglutination reactions for the common serotype-specific $\mathrm{O}$ and $\mathrm{H}$ antigens (Difco and Wellcome Diagnostics) (Kauffmann, 1972), and, where necessary, sugar fermentations (API Carbohydrate System) and biochemical tests for Enterobacteriaceae (Difco) (see also Buchanan \& Gibbons, 1974).

Assessment of virulence. Virulence of the transposon-insertion mutants was assessed by comparing their ability to kill mice with that of the wild-type parent, following oral inoculation. The mice were 6-8-week-old C57BL/COM females, boxed individually and given Clarke's Rat and Mouse pellets and water ad libitum.

Bacterial strains to be tested were grown for $18 \mathrm{~h}$ at $37^{\circ} \mathrm{C}$ in static conditions in $\mathrm{L}$ broth alone (wild-type strains), in $\mathrm{L}$ broth containing $500 \mu \mathrm{g} \mathrm{Ap} \mathrm{ml}{ }^{-1}$ (TnA-insertion mutants), or in $\mathrm{L}$ broth containing $20 \mu \mathrm{g} \mathrm{Tc} \mathrm{ml}^{-1}$ ( $\mathrm{Tn} 10$-insertion mutants). (L broth contains $10 \mathrm{~g}$ tryptone, $5 \mathrm{~g}$ yeast extract and $5 \mathrm{~g} \mathrm{NaCl} 1^{-1} ; \mathrm{pH} 7.5$.) The bacteria were washed at least once in isotonic saline $(0.9 \%, \mathrm{w} / \mathrm{v}, \mathrm{NaCl})$ and $0.1 \mathrm{ml}$ volumes of appropriate dilutions in isotonic saline of these washed cells were then inoculated into each of 4-16 mice. In all tests, at least one control group of mice was inoculated with the wild-type parent and another with isotonic saline. The mice were monitored for up to $14 \mathrm{~d}$, and deaths recorded. Most deaths occurred between 5 and $10 \mathrm{~d}$ following inoculation.

In all, about 500 mutant strains were screened in the present study.

Preparation of plasmid DNA. Crude plasmid DNA was prepared by the method of Silhavy et al. (1984), using lysozyme and $\mathrm{NaOH} / \mathrm{SDS}$. The DNA was then purified by centrifugation to equilibrium in a $\mathrm{CsCl} /$ ethidium bromide gradient over $36 \mathrm{~h}$ at $15^{\circ} \mathrm{C}$ (Maniatis et al., 1982). After removal of the ethidium bromide by butanol extraction (Davis et al., 1980), the DNA was precipitated with ethanol and finally dissolved in $10 \mathrm{~mm}$-Tris, $1 \mathrm{~mm}$ EDTA, pH 8.0.

Restriction-enzyme digests. These were carried out as described by Maniatis et al. (1982).

Preparation of total DNA. Total (i.e. plasmid plus chromosomal) DNA was prepared essentially by the method described by Maniatis et al. (1982) for eukaryotic DNA, except that the bacteria were resuspended in $50 \mathrm{~mm}$ glucose, $10 \mathrm{~mm}$-EDTA, $25 \mathrm{~mm}$-Tris $/ \mathrm{HCl}, \mathrm{pH} 8.0$, containing $5 \mathrm{mg}$ lysozyme $\mathrm{ml}^{-1}$, and kept at $0^{\circ} \mathrm{C}$ for $30 \mathrm{~min}$ before being treated with $0.5 \%$ Sarkosyl, $0.5 \mathrm{M}$-EDTA, pH 8.0, containing $100 \mu \mathrm{g}$ proteinase $\mathrm{K} \mathrm{ml}^{-1}$ (Maniatis $e t$ al., 1982).

Electrophoresis. Horizontal electrophoresis was carried out in $0.6 \%(\mathrm{w} / \mathrm{v})$ agarose gels using Tris/acetate buffer (40 mM-Tris, $20 \mathrm{~mm}$-acetic acid, $2 \mathrm{~mm}$-EDTA, pH 8.1 : Davis et al., 1980). DNA was usually electrophoresed for about $15 \mathrm{~h}$ at $1.5 \mathrm{~V} \mathrm{~cm}^{-1}$ at room temperature.

Hybridization. DNA fragments in agarose gels were transferred to nitrocellulose filters by Southern blotting, and then hybridized to ${ }^{32} \mathrm{P}$-labelled, nick-translated plasmid probes. The procedures employed were as described by Maniatis et al. (1982).

Cloning. Various restriction-digest fragments of the $S$. dublin and S. typhimurium wild-type and mutant plasmids were cloned for restriction mapping and hybridization studies. A given plasmid and the chosen vector, i.e. pACYC184, pAT153 or pUC12 (Table 1), were digested with an appropriate restriction endonuclease and the resultant fragments separated by electrophoresis. Following localization, gel pieces containing the bands of cut vector and plasmid fragment were excised, placed in dialysis bags and subjected to electroelution for $3-4 \mathrm{~h}$ a1 
Table 1. Strains and vectors used

Strain/vector

Salmonella strains

S. dublin 2229

S. typhimurium 1275

S. typhimurium NK337

S. typhimurium TR248

S. typhimurium TR251

S. dublin M51

S. dublin M173\}

S. dublin M114

$S$ typhimurium M242

E. coli strains

E. coli K12(pMR5)

E. coli $\mathrm{HB} 101$

Phage

P22-503

Vectors

pACYC184

pAT 153

pUCl2 (same cloning) site as M13 mpl0)
Properties

Source*

Field outbreak of bovine salmonellosis

Field outbreak of bovine salmonellosis

D. Botstein ${ }^{1}$

D. Botstein ${ }^{1}$

D. Botstein'

$\operatorname{Tn} A$-insertion mutants of

S. dublin 2229 exhibiting diminished virulence in mice

Tn $A$-insertion mutant of $S$. dublin 2229 that retained full virulence

Tn10-insertion mutant

of $S$. typhimurium 1275

exhibiting diminished

virulence in mice

Harbours plasmid pMR5, i.e. RPlts; this

plasmid contains $\operatorname{Tn} A$

hsdS recA

c1 12 am 13 am

$4 \mathrm{kbp} ; \mathrm{Cm}^{\mathrm{r}} \mathrm{Tc}^{\mathrm{r}}$

$3.6 \mathrm{kbp} ; \mathrm{Ap}^{\mathrm{r}} \mathrm{Tc}^{\mathrm{r}}$

$2.8 \mathrm{kbp} ; \mathrm{Ap}^{\mathrm{r}}$
Prepared by the

authors

Prepared by the authors

Prepared by the authors

H. R. Smith ${ }^{2}$

Robinson et al. (1980)

J. G. Williams ${ }^{3}$

D. Botstein 1

M. Kehoe 4

J. G. Williams ${ }^{3}$

Bethesda Research Laboratories, Paisley, UK Dussoix (1969)

Davis et al. (1980)

Chang \& Cohen (1978)

Twigg \& Sherratt (1980)

Messing \& Vieira

(1982)
Reference

Davis et al. (1980)

Davis et al. (1980)

Davis et al. (1980)

* 1, Dr D. Botstein, Dept of Biology, Massachusetts Institute of Technology, Cambridge, MA 02139, USA; 2, Dr H. R. Smith, Central Public Health Laboratory, Colindale Avenue, London NW9 5HT, UK; 3, Dr J. G. Williams, Imperial Cancer Research Fund, Mill Hill, London, UK; 4, Dr M. Kehoe, then at Microbiology Department, Trinity College, Dublin, Eire.

$5 \mathrm{~V} \mathrm{~cm}^{-1}$. The electroeluted DNA was then extracted with phenol/chloroform, precipitated with ethanol and finally dissolved in $10 \mathrm{~mm}$-Tris, $1 \mathrm{~mm}$-EDTA, $\mathrm{pH} \mathrm{8.0.} \mathrm{Following} \mathrm{incubation} \mathrm{of} \mathrm{the} \mathrm{vector} \mathrm{with} \mathrm{alkaline}$ phosphatase, appropriate vector and plasmid fragments were mixed and incubated in the presence of ligation buffer and T4 DNA ligase at $4^{\circ} \mathrm{C}$ for $18 \mathrm{~h}$ (Maniatis et al., 1982). The ligated DNA was extracted with

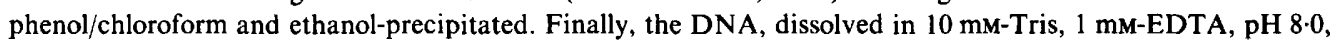
was transformed into $E$. coli $\mathrm{HB} 10 \mathrm{l}$ (Maniatis et al., 1982). Identity of clones was confirmed by restriction digestion and hybridization.

\section{RESULTS}

\section{Mutants exhibiting diminished virulence}

Three mutants were identified that exhibited diminished virulence. Of these, two, designated M51 and M173, were Tn $A$-insertion mutants of $S$. dublin 2229, while the other, designated M242, was a Tn10-insertion mutant of $S$. typhimurium 1275 . Table 2 records the results obtained in separate virulence assays with these three mutants. The assays indicated that the virulence of M51 and M173 was some $10^{4}-10^{5}$-fold less than that of the parent $S$. dublin 2229, i.e. that $10^{4}-$ $10^{5}$ times as many c.f.u. of either mutant were required to achieve the same lethality as a given 
Table 2. Comparison of ability of mutants M51, M173 and M242, and their wild-type parents, to kill mice

The inoculum volume was $0 \cdot 1 \mathrm{ml}$. Numbers of c.f.u. per $0 \cdot 1 \mathrm{ml}$ of undiluted inoculum were, respectively: for wild-type and $M 51,7.3$ and $6.1 \times 10^{7}$; for wild-type and $M 173,4.8$ and $5.0 \times 10^{7}$; for wild-type and M242, 5.2 and 3.9 $\times 10^{7}$. For further details, see Methods.

\begin{tabular}{|c|c|c|c|c|c|c|}
\hline \multirow[b]{3}{*}{$\begin{array}{l}\text { Dilution } \\
\text { inoculated }\end{array}$} & \multicolumn{6}{|c|}{ Mice killed/mice inoculated } \\
\hline & \multicolumn{2}{|c|}{ Expt 1} & \multicolumn{2}{|c|}{ Expt 2} & \multicolumn{2}{|c|}{ Expt 3} \\
\hline & $\begin{array}{l}\text { S. dublin } \\
2229\end{array}$ & M51 & $\begin{array}{c}\text { S. dublin } \\
2229\end{array}$ & M173 & $\begin{array}{l}\text { S. typhimurium } \\
1275\end{array}$ & M242 \\
\hline Undiluted & - & $9 / 16$ & $4 / 4$ & $0 / 4$ & - & - \\
\hline $10^{-1}$ & - & $0 / 16$ & $4 / 4$ & $1 / 4$ & - & - \\
\hline $10^{-2}$ & - & $0 / 16$ & $4 / 4$ & $0 / 4$ & - & $2 / 7$ \\
\hline $10^{-3}$ & - & $0 / 16$ & $3 / 4$ & $0 / 4$ & $6 / 7$ & $3 / 7$ \\
\hline $10^{-4}$ & $7 / 8$ & - & $3 / 4$ & $0 / 4$ & $5 / 7$ & $0 / 7$ \\
\hline $10^{-5}$ & $5 / 8$ & - & $2 / 4$ & $0 / 4$ & $4 / 7$ & $0 / 7$ \\
\hline $10^{-6}$ & - & - & - & - & $1 / 7$ & - \\
\hline
\end{tabular}

inoculum of 2229. The virulence of M242 was some $10^{2}-10^{3}$-fold less than that of the parent $S$. typhimurium 1275. Assays of the virulence of M51, M173 and M242 were repeated on at least two further occasions, using a similar experimental design. These repeat assays gave similar results (not shown) to those recorded in Table 2.

\section{General properties of mutants M51, M173 and M242}

No differences were observed between the mutants and their respective parents in colony morphology, qualitative agglutination reactions, biochemical properties or resistance to rabbit serum (Taylor et al., 1972). The in vitro growth rates of $S$. dublin M51 and M173 in L broth at $37^{\circ} \mathrm{C}$ were the same as that of the parent wild-type. By contrast, the in vitro growth rate of $S$. typhimurium M242, as with other, virulent, $\mathrm{Tn} 10$-insertion mutants, was up to $50 \%$ less than that of the parent.

\section{Plasmid content}

Electrophoretic analysis, using plasmids of known size as markers (not shown), indicated that $S$. dublin 2229 harboured one plasmid species of $69 \mathrm{kbp}$, while $S$. typhimurium harboured at least two species, one of $88 \mathrm{kbp}$ and the other of about $3 \mathrm{kbp}$. The single plasmid species present in $S$. dublin 2229 and the larger species present in S. typhimurium 1275 were of similar size to those plasmids which have previously been implicated in the virulence of these serotypes (Jones et al., 1982; Terakado et al., 1983). Electrophoretic analysis also gave values of 71 and $75 \mathrm{kbp}$ for the plasmids present in S. dublin M51 and M173, respectively, and of $96 \mathrm{kbp}$ for the larger plasmid present in $S$. typhimurium M242. These mutant plasmids were, therefore, larger than the corresponding wild-type plasmids, indicating that transposon insertion into the plasmids had probably occurred in all three mutants.

$S$. typhimurium M242 was cured of its $96 \mathrm{kbp}$ plasmid, containing $\operatorname{Tn} 10$, by selecting for tetracycline sensitivity (Bochner et al., 1980). The virulence of the cured derivative was about $10^{2}$-fold less than that of M242, i.e. $10^{4}-10^{5}$-fold less than that of 1275 (data not shown).

\section{Mapping of transposon location}

S. dublin M51 and M173. Restriction digest experiments with enzymes for which there is no recognition site in Tn $A$ (EcoRI, HindIII, SacI, SalI, XhoI) indicated that both M51 and M173 contained a single $\operatorname{Tn} A$ insertion in the $70 \mathrm{kbp}$ plasmid, and that the sites of insertion in the two mutants were not more than $10 \mathrm{kbp}$ apart. In M51, Tn $A$ insertion had taken place with the deletion of some $2-3 \mathrm{kbp}$ of DNA (Fig. $1 a$ ). More detailed mapping, including the use of enzymes for which there are asymmetrically positioned sites in $\operatorname{Tn} A(C l a I, B a m H I)$, indicated 


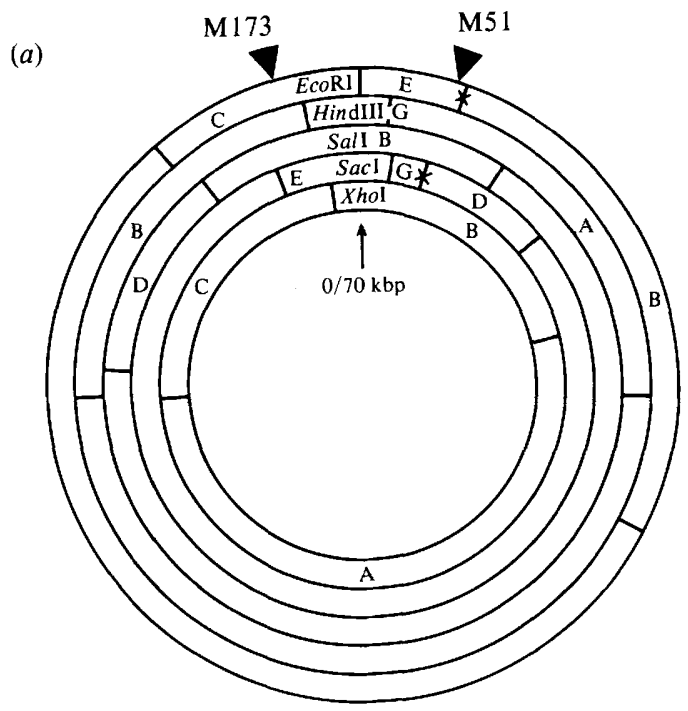

(b)

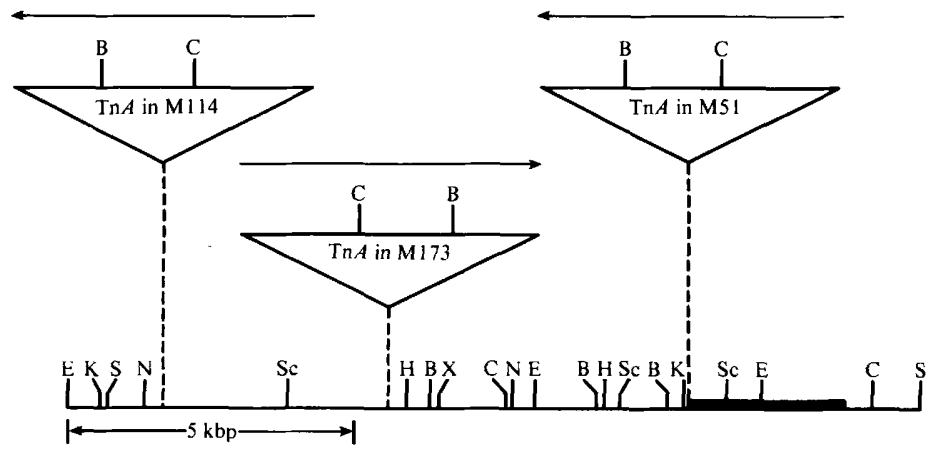

Fig. 1 ( a) Partial restriction map of the $S$. dublin 2229 plasmid showing approximate insertion sites of $\operatorname{Tn} A$ in M51 and M173 (black wedges). The plasmid is drawn to scale on the assumption that its size is $70 \mathrm{kbp}$. The marked EcoRI and SacI sites are missing in M5I.

(b) Restriction map of approx. $15 \mathrm{kbp}$ stretch of the $70 \mathrm{kbp}$ plasmid of $S$. dublin 2229 showing the sites of insertion of $\operatorname{Tn} A$ in M51, M114 and M173. The thick line indicates the extent of the deletion in M51. The arrows indicate the orientation of $\operatorname{Tn} A$ in each mutant. Restriction enzyme abbreviations: $B$, BamHI; C, ClaI ; E, EcoRI; H, HindIII; K, KpnI; N, NdeI; S, SalI ; Sc, SacI; X, XhoI.

that the Tn $A$ copies in M51 and M173 were located $5 \mathrm{kbp}$ apart and were inserted in opposite orientations (Fig. $1 b$ ). It was also possible to map the position of a neighbouring $\operatorname{Tn} A$ insertion found in a third mutant, designated M114, that retained full virulence in the mouse assay. This latter insertion was about $4 \mathrm{kbp}$ from that in M173, on the opposite side from that in M51 (Fig. $1 b)$.

S. typhimurium M242. Restriction digest experiments with enzymes for which there is no restriction site in $\mathrm{Tn} 10$ ( $\mathrm{SacI}, \mathrm{SalI}, \mathrm{XhoI}$ ) indicated that in M242 a single copy of $\mathrm{Tn} 10$ was inserted into the $90 \mathrm{kbp}$ plasmid present in 1275. Mapping with these enzymes, and with others that cut Tn 10 asymmetrically (EcoRI, HindIII), permitted the construction of the restriction map illustrated in Fig. 2.

Apparent similarity of transposon insertion sites. Restriction digest profiles of the 70 and $90 \mathrm{kbp}$ plasmids of S. dublin 2229 and S. typhimurium 1275, respectively, were clearly different for any given restriction enzyme. However, the restriction maps for the regions of transposon insertion in $S$. dublin M51 and M173, on the one hand (Fig. 1 b), and in S. typhimurium M242 on the other 


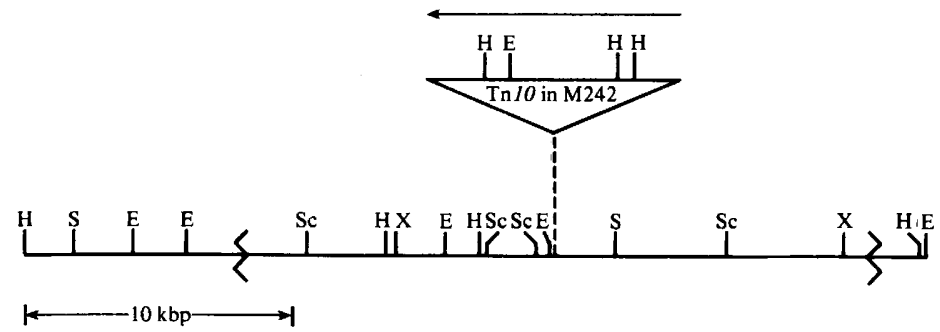

Fig. 2. Restriction map of approx. $35 \mathrm{kbp}$ stretch of the $90 \mathrm{kbp}$ plasmid of $S$. typhimurium 1275 showing the site of insertion in M242 of Tn10, whose orientation is indicated by the arrow. Restriction enzyme abbreviations as in Fig. $1(b)$. The zig-zag lines indicate the probable maximum limits of interserotype homology (see also text).

(Fig. 2), were markedly similar. In fact, the distribution of sites in the XhoI/SalI fragments containing the transposon insertions in M51 and M242 appeared to be identical, suggesting that these fragments must at least share substantial homology.

The existence of homology in the regions of transposon insertion in the two plasmids had been confirmed at an early stage of the work when it had been observed that the SalI fragment encompassing the sites of $\operatorname{Tn} A$ insertion in S. dublin M51 and M173 hybridized to the SalI, XhoI and $P$ st I fragments of the $S$. typhimurium M242 plasmid that contained the $\mathrm{Tn} 10$ insertion (Fig. $3 a, b)$. Subsequently, it was found that the similar XhoI/SalI fragments from the two serotypes hybridized strongly. More detailed studies indicated that the homology extended leftwards beyond the left-hand $S a c I$ site of the $S$. dublin 2229 plasmid (Fig. 1 b) but ceased before the SalI site was reached. The probable maximum limits of the inter-serotype homology in this region of the 1275 plasmid are indicated in Fig. 2. Whereas the left-hand limit must be approximately correct, the right-hand limit merely indicates the end of known similarity in restriction-site distribution.

\section{Possible presence of chromosomal transposon insertions}

The theoretical possibility existed that further transposon copies could have been inserted into the chromosomal DNA of the three mutants. To investigate this possibility, autoradiograph bands that appeared when a clone containing the relevant transposon was hybridized to restriction digests of mutant total DNA were compared with those appearing when the clone was hybridized to parallel digests of plasmid DNA from the same strain. For all three mutants, the autoradiograph bands produced by hybridization of the appropriate clone to total DNA corresponded to those produced when the clone was hybridized to plasmid DNA. It could therefore be concluded that, in the case of each mutant, the clones were hybridizing to plasmid DNA contained within the total DNA, but were failing to hybridize to chromosomal DNA. Evidently, none of the three mutants contained a copy of the inserted transposon in its chromosomal DNA.

\section{DISCUSSION}

Transposon insertion interrupts the continuity of a given DNA sequence and may therefore be expected to impair or abolish its genetic function. The fact that the single transposon insertions in the three mutants that exhibited diminished virulence were all into the large plasmids harboured by $S$. dublin and $S$. typhimurium indicates that these plasmids play an important role in virulence expression. In permitting this conclusion, the present work corroborates the previous findings of other workers, made on the basis of curing and conjugation experiments (Jones et al., 1982; Terakado et al., 1983).

It was of interest that a single transposon insertion was sufficient to cause such a large decrease in virulence in $S$. dublin M51 and M173. In each of these mutants, the insertion must have destroyed the whole of the contribution of the plasmid to virulence (as assayed in the 


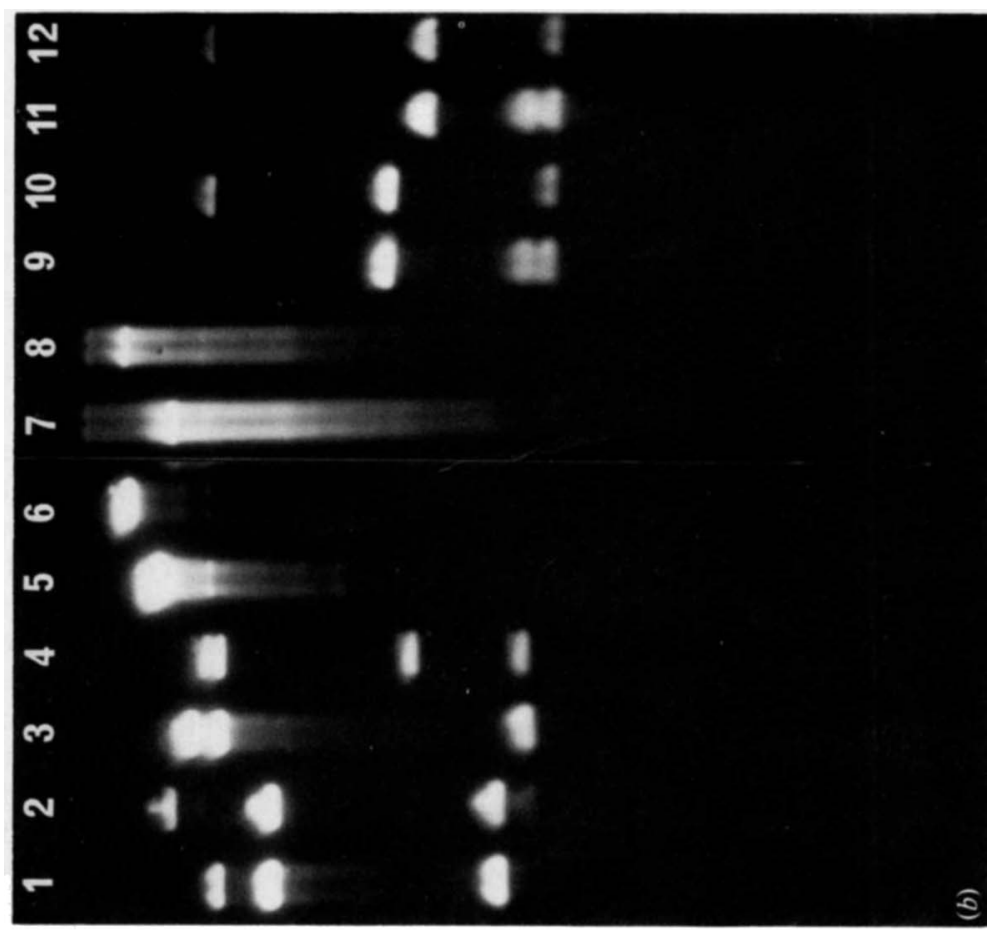

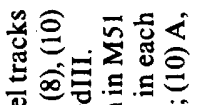

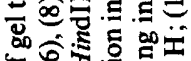

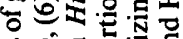

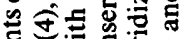

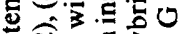

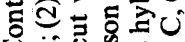

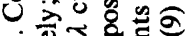
तิ 可证

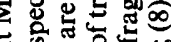
要 볼. 枹

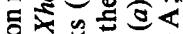
+

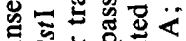

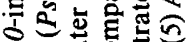

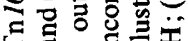

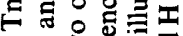

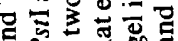

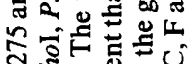
ฟ

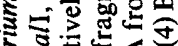

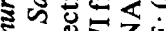

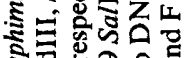
ติำ

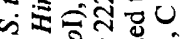

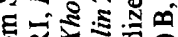
은 은 엔 돈

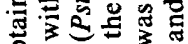
$\circ 0$ 잉

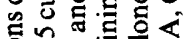

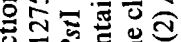

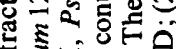

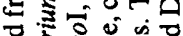

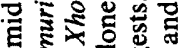
政然U 2.

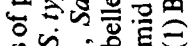

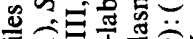

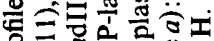

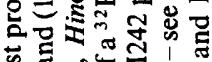

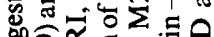

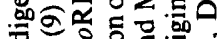

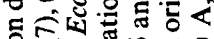

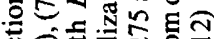
흔 可和产 记

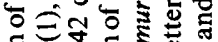

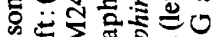

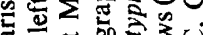
西

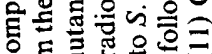

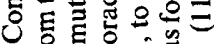

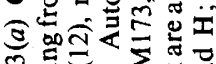

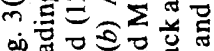

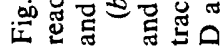


animal model used in this study), since curing M173 of its plasmid failed to diminish virulence any further (E. J. Manning, G. D. Baird \& P. Jones, unpublished). This was not the case with $S$. typhimurium M242, since curing this strain of the larger plasmid did lead to a further decrease in virulence (see above). The cured derivatives of $S$. dublin 2229 and S. typhimurium 1275, and also M51 and M173, were still able to kill mice if administered in sufficient quantity. This residual virulence must have been chromosomally encoded.

The fact that the transposon insertions in $S$. dublin M51 and M173 were only $5 \mathrm{kbp}$ apart suggests that the insertions could have taken place into a discrete sequence that encoded the virulence factors. This possibility is supported by further observations. Firstly, while the region encompassing the sites of $\operatorname{Tn} A$ insertion in $S$. dublin M51 and M173 appeared, on the basis of restriction sites, to be very similar to the region into which $\mathrm{Tn} 10$ is inserted in $S$. typhimurium M242, flanking sequences to the left and right of this region were clearly dissimilar. The virulence-impairing insertions in the two serotypes appear, therefore, to have been into what may be closely related sequences of limited length. Secondly, while the $\operatorname{Tn} A$ insertion in $S$. dublin M114 was only $4 \mathrm{kbp}$ distant from that in M173, it was on the edge of the region of putative identity, and also failed to diminish virulence. The possibility therefore exists that the regions of apparent homology represent a virulence-encoding sequence that has been preserved during the evolutionary divergence of the two serotypes.

The finding of homology between sequences of $S$. dublin and $S$. typhimurium plasmids is in accord with the recent work of Popoff et al. (1984), who observed homology between these plasmids and also those of other Salmonella serotypes. Hale et al. (1983) earlier observed homology in the large (185-215 kbp) plasmids present in Shigella flexneri, Shigella sonnei and enteroinvasive Escherichia coli. These latter authors also provided evidence for the existence of a discrete virulence-encoding region in the $S$. flexneri plasmid, since a mutant carrying a deletion of unspecified size in this plasmid was avirulent.

There are at least three possible explanations for the fact that transposon insertions that were $5 \mathrm{kbp}$ apart in the $S$. dublin plasmid should both apparently destroy the total virulence capacity of the plasmid. These are (i) that several plasmid genes play an equally indispensable role in virulence expression, (ii) that at least one of the transposons was inserted into a regulatory sequence, and (iii) that at least one of the transponsons was exerting polarity effects on distant sequences. Genetic and sequencing analyses will be required to resolve this question. It is only possible to speculate at this stage on reasons why the $\operatorname{Tn} 10$ insertion in $S$. typhimurium M242 did not reduce virulence further. One possibility is that this was due to the relative importance of interrupted sequences for virulence expression. Another is that the $S$. typhimurium plasmid could contain further virulence genes, located elsewhere, that are not possessed by the $S$. dublin plasmid.

The finding that only one transposon copy was inserted into each mutant was not unexpected, in the case of $\mathrm{M} 242$, at least. The transposition frequency of $\mathrm{Tn} 10$ from a phage suicide vector is about $2 \times 10^{-6}$ (Foster et al., 1981), and this normally ensures that only one copy of this transposon is present in each mutant clone (Davis et al., 1980). The frequency of transposition of $\operatorname{Tn} A$ is higher, i.e. about $1 \times 10^{-4}$ and $3 \times 10^{-8}$ per MDal of recipient plasmid or chromosomal DNA, respectively (Kretschmer \& Cohen, 1977) and the possibility of multiple transposon insertions in a given mutant might, therefore, be correspondingly greater. Nevertheless, this would be unlikely to result in multiple insertions into the same replicon, owing to immunity effects (Robinson et al., 1977).

It might have been expected that some mutants showing diminished virulence would have been found that had chromosomal transposon insertions. Thus, it is known that mutations in certain chromosomal metabolic loci, e.g. those in the galE locus (Germanier \& Fürer, 1975) and in the aro $A$ locus (Hoiseth \& Stocker, 1981) result in loss of virulence in Salmonella. That no such insertions were found in the present study may simply have been due to the relatively small numbers of mutants screened.

The authors gratefully acknowledge the skilled technical assistance of Miss Gillian D. Pullinger, Miss Christine M. Williamson and Mrs Vivien Bentley. 


\section{REFERENCES}

BAIRD, G. D. \& MANNing, E. J. (1984). Molecular evidence for plasmid involvement in the virulence of Salmonella dublin. In Priority Aspects of Salmonellosis Research, pp. 147-153. Edited by H. E. Larsen. Brussels: Commission of the European Communities (Publication EUR 9197EN).

Bochner, B. R., Huang, H. C., Schieven, G. L. \& AMEs, B. N. (1980). Positive selection for loss of tetracyline resistance. Journal of Bacteriology 143, 926-933.

BoYer, H. W. \& Roulland-Dussoix, D. (1969). A complementation analysis of the restriction and modification of DNA in Escherichia coli. Journal of Molecular Biology 41, 459-472.

Buchanan, R. E. \& GibBons, N. E. (1974). Bergey's Manual of Determinative Bacteriology, 8th edn. Baltimore: Williams \& Wilkins.

Chang, A. C. Y. \& Cohen, S. N. (1978). Construction and characterization of amplifiable multicopy DNA cloning vehicles derived from the P15A cryptic miniplasmid. Journal of Bacteriology 134, 11411156.

DAvis, R. W., Botstein, D. \& Roth, J. R. (1980). Advanced Bacterial Genetics. Cold Spring Harbor, New York: Cold Spring Harbor Laboratory.

Foster, T. J., Davis, M. A., Roberts, D. E., TAKeshita, K. \& KLeCKNeR, N. (1981). Genetic organization of transposon $\mathrm{Tn} 10$. Cell 23, 201-213.

GermanIER, R. \& FüreR, A. (1975). Isolation and characterization of gaIE mutant Ty21a of Salmonella typhi: a candidate strain for a live, oral typhoid vaccine. Journal of Infectious Diseases 131, 553558.

Hale, T. L., Sansonetti, P. J., Schad, P. A., Austin, S. \& Formal, S. B. (1983). Characterization of virulence plasmids and plasmid-associated outer membrane proteins in Shigella flexneri, Shigella sonnei and Escherichia coli. Infection and Immunity 40 , 340-350.

HoISETH, S. K. \& STOCKeR, B. A. D. (1981). Aromaticdependent $S$. typhimurium are non-virulent and effective as live vaccines. Nature, London 291, 238239.

JoNes, G. W., Rabert, D. K., Svinarich, D. M. \& WhITFIELD, H. J. (1982). Association of adhesive, invasive, and virulent phenotypes of Salmonella typhimurium with autonomous 60 -megadalton plasmids. Infection and Immunity 38, 476-486.

KaUfFMANN, S. (1972). Serological Diagnosis of Salmonella Species. Copenhagen: Munksgaard.

KRetschmer, P. J. \& Cohen, S. N. (1977). Selected translocation of plasmid genes: frequency and regional specificity of translocation of the $\operatorname{Tn} 3$ element. Journal of Bacteriology 130, 888-899.
Levy, S. B., Clowes, R. C. \& Koenig, E. L. (1981). Molecular Biology, Pathogenicity and Ecology of Bacterial Plasmids. New York and London: Plenum Press.

Maniatis, T., Fritsch, E. F. \& Sambrook, J. (1982) Molecular Cloning. Cold Spring Harbor, New York: Cold Spring Harbor Laboratory.

Manning, E. J., BaiRd, G. D. \& Jones, P. W. (1984). Possible plasmid involvement in the virulence of Salmonella dublin. Biochemical Society Transactions 12, 847-848.

Messing, J. \& Vieira, J. (1982). A new pair of M13 vectors for selecting either DNA strand of doubledigest restriction fragments. Gene 19, 269-276.

Miller, J. H. (1972). Experiments in Molecular Genetics. Cold Spring Harbor, New York: Cold Spring Harbor Laboratory.

Popoff, M. Y., Miras, I., Coynault, C., Lasselin, C. \& Pardon, P. (1984). Molecular relationships between virulence plasmids of Salmonella serotypes typhimurium and dublin and large plasmids of other Salmonella serotypes. Annales de microbiologie 135A, 389-398.

Robinson, M. K., Bennett, P. M. \& Richmond, M. H. (1977). Inhibition of TnA translocation by $\operatorname{TnA}$. Journal of Bacteriology 129, 407-414.

Robinson, M. K., Bennett, P. M., Falkow, S. \& DoDD, H. M. (1980). Isolation of a temperaturesensitive derivative of RP1. Plasmid 3, 343-347.

Sansonetti, P. J., Kopecko, D. J. \& Formal, S. B. (1981). Shigella sonnei plasmids: evidence that a large plasmid is necessary for virulence. Infection and Immunity 34, 75-83.

Sansonetti, P. J., Kopecko, D. J. \& Formal, S. B. (1982). Involvement of a plasmid in the invasive ability of Shigella flexneri. Infection and Immunity 35 , $852-860$.

Silhavy, T. J., Berman, M. L. \& Enquist, L. W. (1984). Experiments with Gene Fusions. Cold Spring Harbor, New York: Cold Spring Harbor Laboratory.

TAYLOR, P. W., Roberts, A. P. \& Gower, P. L. (1972). Evaluation of a technique for the estimation of serum bactericidal activity against Gram-negative organisms. Medical Laboratory Technology 29, 272279.

Terakado, N., Sekizaki, T., Hashimoto, K. \& NaITOH, S. (1983). Correlation between the presence of a fifty-megadalton plasmid in Salmonella dublin and virulence for mice. Infection and Immunity 41 , 443-444.

Twigg, A. J. \& Sherratt, D. (1980). Trans-complementable copy number mutants of plasmid ColE1. Nature, London 283, 216-218. 